\title{
PEMANFAATAN INFORMASI TEKNOLOGI DALAM PENGELOLAAN BISNIS PADA UMK KULIT SAPI DAN KAMBING DI KECAMATAN GUNUNGPUTRI
}

\author{
Nazatul Magfiroh ${ }^{1}$ dan Muhammad Nur Rizqi ${ }^{2}$ \\ nazatulmagfiroh42@gmail.com ${ }^{1}$ \\ mn.rizqi6@gmail.com ${ }^{2}$ \\ Prodi Akuntansi, Fakultas Ekonomi dan Bisnis, Universitas Ibn Khaldun Bogor ${ }^{1,2}$
}

\begin{abstract}
ABSTRAK
Teknologi informasi memiliki kekuatan untuk mengembangkan industri dan mentransformasikan bagaimana bisnis dijalankan. Menurut Undang-Undang Nomor 11 Tahun 2008 Tentang Informasi dan Transaksi Elektonik bahwa pemanfaatan teknologi informasi berperan penting dalam perdagangan dan pertumbuhan perekonomian nasional untuk mewujudkan kesejahteraan masyarakat. Selain Teknologi Informasi yang dimanfaatkan adapula metode yang digunakan dalam memproduksi untuk menghasilkan suatu barang yaitu menerapkan perhitungan biaya diferensial dalam pengambilan pengambilan keputusan menerima atau menolak pesanan secara khusus. Tujuan dari penelitian ini ialah menerapkan perhitungan biaya diferensial dengan menggunakan metode menerima atau menolak pesanan khusus pada UMKM Bast Grup yang berada di Kecamatan Gunungputri guna membantu memberikan ide tentang pemanfaat teknologi informasi dengan cara berjualan di media sosial di tengah pandemi guna menghasilkan keuntungan bagi UMKM tersebut Dan hasil penilitian yang telah dibuat menunjukkan bahwa penerapan metode menerima/menolak pesanan khusus ini dengan menjumlahkan seluruh biaya produksi dan keuntungan yang diinginkan oleh UMKM . Hasil perhitungan menunjukkan bahwa BAST Grup harus menjual sarung tangan secara online dengan menggunakan media sosial guna mendapatkan tambahan keuntungan di produksinya.
\end{abstract}

Kata Kunci : Teknologi Informasi, Biaya Diferensial, Menerima/Menolak Pesanan Khusus

\section{PENDAHULUAN}

Coronavirus adalah keluarga besar virus yang menyebabkan penyakit mulai dari gejala ringan sampai berat. Ada setidaknya dua jenis coronavirus yang diketahui menyebabkan penyakit yang dapat menimbulkan gejala berat seperti Middle East Respiratory Syndrome (MERS) dan Severe Acute Respiratory Syndrome (SARS). Coronavirus Disease 2019 (COVID-19) adalah penyakit jenis baru yang belum pernah diidentifikasi sebelumnya pada manusia. Virus penyebab COVID-19 ini dinamakan SarsCoV-2. Virus corona adalah zoonosis (ditularkan antara hewan dan manusia). Penelitian menyebutkan bahwa SARS ditransmisikan dari kucing luwak (civet cats) ke manusia dan MERS dari unta ke manusia. Adapun, hewan yang menjadi sumber penularan COVID-19 ini masih belum diketahui (Kemenkes, 2020) 
Tanda dan gejala umum infeksi COVID-19 antara lain gejala gangguan pernapasan akut seperti demam, batuk dan sesak napas. Masa inkubasi rata-rata 5-6 hari dengan masa inkubasi terpanjang 14 hari. Pada kasus COVID-19 yang berat dapat menyebabkan pneumonia, sindrom pernapasan akut, gagal ginjal, dan bahkan kematian. Tanda-tanda dan gejala klinis yang dilaporkan pada sebagian besar kasus adalah demam, dengan beberapa kasus mengalami kesulitan bernapas, dan hasil rontgen menunjukkan infiltrat pneumonia luas di kedua paru (Kemenkes, 2020).

Pada 31 Desember 2019, WHO China Country Office melaporkan kasus pneumonia yang tidak diketahui etiologinya di Kota Wuhan, Provinsi Hubei, Cina. Pada tanggal 7 Januari 2020, Cina mengidentifikasi pneumonia yang tidak diketahui etiologinya tersebut sebagai jenis baru coronavirus (coronavirus disease, COVID-19). Pada tanggal 30 Januari 2020 WHO telah menetapkan sebagai Kedaruratan Kesehatan Masyarakat Yang Meresahkan Dunia/ Public Health Emergency of International Concern (KKMMD/PHEIC). Penambahan jumlah kasus COVID-19 berlangsung cukup cepat dan sudah terjadi penyebaran antar negara (Kemenkes, 2020).

Pada tanggal 2 Maret 2020, Indonesia melaporkan kasus konfirmasi COVID-19 sebanyak 2 kasus. Sampai dengan tanggal 22 September 2020, Indonesia sudah melaporkan 252.923 kasus konfirmasi COVID-19 dari 24 Provinsi. Berdasarkan bukti ilmiah, COVID-19 dapat menular dari manusia ke manusia melalui percikan batuk/bersin (droplet), tidak melalui udara. Orang yang paling berisiko tertular penyakit ini adalah orang yang kontak erat dengan pasien COVID-19 termasuk yang merawat pasien COVID-19. Rekomendasi standar untuk mencegah penyebaran infeksi adalah melalui cuci tangan secara teratur menggunakan sabun dan air bersih, menerapkan etika batuk dan bersin, menghindari kontak secara langsung dengan ternak dan hewan liar serta menghindari kontak dekat dengan siapapun yang menunjukkan gejala penyakit pernapasan seperti batuk dan bersin. Selain itu, menerapkan Pencegahan dan Pengendalian Infeksi (PPI) saat berada di fasilitas kesehatan terutama unit gawatdarurat (Kemenkes, 2020).

Dengan adanya pandemik COVID-19 yang terjadi di seluruh negara termasuk salah satunya adalah Negara Indonesia, maka Kementerian Kesehatan dan Pemerintahan melakukan Instruksi yaitu melarang warga nya untuk keluar rumah , dilarang berdekatan dan dilarang berkumpul atau bahasa yang sering kita kenal social distancing, PSBB (Pembatasan Sosial Berskala Besar), melakukan kegiatan di dalam rumah seperti beribadah, bekerja (work from home), belajar mengajar yang selama ini dilakukan secara Tatap Muka maka dilakukan metode Jarak Jauh secara Daring sebagai upaya memutus mata rantai penyebaran COVID-19.

Dengan kondisi di masa pandemi ini membuat ekonomi terkapar, aktivitas sosial dan ekonomi hampir lumpuh dan membuat roda perekonomian terhenti. Begitu pula dengan UMKM Bast Grup yang memproduksi sebuah tas yang terbuat dari kulit kambing dan sapi, dan hasil nya akan di kirim ke pabrik-pabrik sesuai dengan pesanan yang diminta. Semenjak corona pendapatan menjadi turun, pabrik-pabrik yang biasa memesan tas pada masa corona ini hanya melakukan sedikit orderan, kemudian UMKM Bast Grup mencoba membuat sarung tangan yang bahan baku nya sama terbuat dari kulit kambing dan 
sapi namun pendapatan yang dihasilkan belum diketahui apakah laba atau rugi,selain itu dimasa pandemi ini biaya bahan baku menjadi naik..

Pada penelitian ini, penulis melakukan kegiatan Program Kerja Kuliah Nyata atau yang kita kenal dengan istilah KKN untuk membantu meningkatkan kembali Pendapatan Bast Grup yaitu sebuah

\section{METODE PELAKSANAAN}

Metode dalam penelitian ini menggunakan jenis penilitan deskriptif kuantitatif yaitu penelitian yang menggambarkan suatu keadaan atau fenomena tertentu secara sistematis sehingga memperoleh suatu kesimpulan umum yang menggambarkan tentang apa yang diteliti serta mengolah data berupa angka-angka dan kemudian di analisis menggunakan analisis statistik. Adapun variabel dalam penelitian ini adalah pengambilan keputusan dengan menggunakan analisis biaya diferensial dengan menerima atau menolak pesanan secara khusus dan menggunakan pemanfaatan media tekonologi dan informasi.

Biaya depresiasi merupakan keputusan manajemen jangka panjang dan merupakan alokasi secara periodik atas harga pokok aktiva tetap yang dibeli pada waktu masa lampau. Depresiasi berhungan dengan pengambilan keputusan jangka panjang dan hanya dipengaruhi pada saat penanaman modal diambil.
UMKM dibidang jahit, dengan memanfaatkan teknologi informasi dengan cara mempromosikan produk yang sudah jadi melalui media sosial contohnya WhatsApp, Instagram, dan Facebook, dan melakukan beberapa metode untuk membandingkan biaya yang telah dikeluarkan menguntungkan UMKM Bast Grup atau tidak.

Data yang dihasilkan berupa angka dari hasil interview mengenai produksi pesanan khusus UMKM Bast Grup sebuah usaha yang memproduksi sarung tangan dari kulit sapi dan kambing di Kecamatan Gunungputri yang digunakan untuk pengambilan keputusan menerima atau menolak pesanan khusus serta menggunakan metode titik tertinggi dan titik terendah sebagai teknik pemisahan biaya semivariabel untuk membantu manajemen dalam mengambil keputusan yang akan diambil.

Lokasi penelitian ini dilakukan dilakukan pada Bast Grup yang berlokasi di Kecamatan Gunung Putri, Kabupaten Bogor. Sumber data yang digunakan oleh peneliti yaitu sumber data sekunder yang diperoleh peneliti dari hasil interview antara penulis dengan manajemen umkm mengenai biaya produksi (terdiri dari biaya bahan baku, bahan ponolong, administrasi dan penjualan) dan informasi lainnya yang terkait dengan penelitian ini adalah dokumentasi.

\section{HASIL PENELITIAN DAN PEMBAHASAN}

Dalam menjalankan kegiatan produksinya, UMKM sering dihadapi dengan berbagai masalah krisis ekonomi, apa lagi saat ini Indonesia dan Negara Lainnya sedang di hadapi dengan masalah Covid-19 dimana banyak karyawan yang di
PHK karena perusahaan tidak bisa beroperasi. Sebagai seorang manajer harus bisa membuat keputusan dengan berbagai altenatif dalam mengelola UMKM nya. Pengambilan keputusan sangat penting dilakukan oleh seorang manajer dalam 
menyelesaikan permasalahan di masa pandemi ini, mengerahkan sumber daya yang dimiliknya demi mencapai tujuan yang diinginkan oleh UMKM. Salah satu altenatif dalam menentukan suatu keputusan yaitu menerima atau menolak pesanan khusus. Pesanan khusus adalah pesanan diluar penjualan normal, dengan pesanan khusus diluar kegiatan normal yang dilakukan oleh UMKM, yang biasanya dengan harga yang lebih rendah dari harga jual normal. UMKM seringkali menerima pesanan khusus dari Customer tanpa memikirkan laba atau rugi dengan adanya pesanan khusus tersebut.

Pada bulan Juli 2020 UMKM Bast Grup menjual sarung tangan sebanyak 1000 dengan biaya produksi sebagai berikut :

> Berikut Kalkulasi Biaya Produksi tanpa pesanan khusus sarung tangan bulan Juni 2020 :

Tabel 1. Biaya Produksi sarung tangan bulan juni 2020

\begin{tabular}{|l|l|}
\hline \multicolumn{1}{|c|}{ Jenis Biaya Produksi } & \multicolumn{2}{c|}{ Jumlah Biaya Produksi } \\
\hline Kulit Sapi = Rp 12.000 @ 20lbr & $\mathrm{Rp} 240.000$ \\
\hline Kulit Kerbau = Rp 13.500 @ 35lbr & $\mathrm{Rp} 472.500$ \\
\hline Kulit Domba = Rp 70.000 @ 55lbr & $\mathrm{Rp} 3.850 .000$ \\
\hline Kulit Kambing = Rp 70.500 @ 70lbr & $\mathrm{Rp} 3.877 .500$ \\
\hline Biaya Bahan Pendukung (Aksesories) & $\mathrm{Rp} 2.500 .000$ \\
\hline Biaya Transportasi \& Angkut & $\mathrm{Rp} 3.750 .000$ \\
\hline Beban Gaji Pekerja Produksi & $\mathrm{Rp} \mathrm{5.000.000}$ \\
\hline Beban Gaji Helper & $\mathrm{Rp} 500.000$ \\
\hline Beban Listrik & $\mathrm{Rp} 3.000 .000$ \\
\hline Beban Administrasi dan umum lainnya & $\mathrm{Rp} 1.500 .000$ \\
\hline Total Biaya Pesanan Khusus & $\mathrm{Rp} \mathrm{24.690.000}$ \\
\hline
\end{tabular}

Sumber : Berdasarkan hasil wawancara dengan pemilik UMKM

$>$ Perhitungan diatas maka Laporan Laba Ruginya adalah sebagai berikut :

Penjualan $\quad: 1000 \times$ Rp $32.000=$ Rp 32.000.000

Biaya Produksi $: 1.000 \times$ Rp $24.690=\operatorname{Rp} 24.690 .000$

Laba Bersih

Rp 7.310.000

Berdasarkan perhitungan laba rugi tanpa pesanan khusus ternyata UMKM Bast Grup mendapatkan pendapatan sebesar Rp 32.000.000, biaya produksi yang dikeluaran sebesar Rp 24.690.000 dan mendapatkan laba bersih sebesar Rp 7.310.000.

Menerima pesanan atau pesanan khusus merupakan keputusan altenatatif yang dilakukan oleh manajemen UMKM, keputusan tersebut mempengaruh laporan laba rugi jadi manajemen harus berhati-hati dalam mengambil keputusan, terlebih di masa pandemi ini bahan baku menjadi mahal karena banyak toko-toko yang tutup dan jika pun ada jaraknya yang lumayan sehingga memakan waktu yang lama biaya pengangkutan barang akan menjadi naik. Setelah adanya perhitungan ini penulis ingin memberikan sebuah ide bagi manajemen UMKM Bast Grup untuk mempromosikan sarung tangan melalu media sosial seperti Whatsapp dan Instagram, karena pada saat masa corona ini banyak orang-orang yang beralih berjualan 
secara online, karena adanya Pembatasan Sosial Bersekala Besar (PSBB) dan social distancing, dan dengan adanya media social ini diharapkan agar penjualan tetap berjalan. Penjualan secara online tentunya akan menambah biaya seperti membayar tagihan wifi setiap bulannya, namun jika dilakukan bisa mengatur dengan cara tetap berjualan secara offline dan online, ini akan menambah pendapatan dan penjualan, dan tentunya ada biaya pengiriman juga. Jika UMKM Bast Grup memproduksi pesanan tanpa khusus sebanyak 1.000 dan ditambah menerima /menolak pesanan dengan perkiraan sebanyak 500 .

Tabel 2. Biaya Produksi pesanan khusus sarung tangan

\begin{tabular}{|l|l|}
\hline \multicolumn{1}{|c|}{ Jenis Biaya Produksi } & \multicolumn{2}{c|}{ Jumlah Biaya Produksi } \\
\hline Kulit Sapi = Rp 12.000 @ 30lbr & $\mathrm{Rp} 360.000$ \\
\hline Kulit Kerbau = Rp 13.500 @ 52,5lbr & $\mathrm{Rp} 708.750$ \\
\hline Kulit Domba = Rp 70.000 @ 82,5lbr & $\mathrm{Rp} 5.775 .000$ \\
\hline Kulit Kambing = Rp 70.500 @ 105lbr & $\mathrm{Rp} 7.402 .500$ \\
\hline Biaya Bahan Pendukung (Aksesories) & $\mathrm{Rp} 3.750 .000$ \\
\hline Biaya Transportasi \& Angkut & $\mathrm{Rp} 5.625 .000$ \\
\hline Beban Gaji Pekerja Produksi & $\mathrm{Rp} 5.000 .000$ \\
\hline Beban Gaji Helper & $\mathrm{Rp} 500.000$ \\
\hline Beban Listrik & $\mathrm{Rp} 4.500 .000$ \\
\hline Beban Wifi & $\mathrm{Rp} 250.000$ \\
\hline Beban Administrasi dan umum lainnya & $\mathrm{Rp} 2.250 .000$ \\
\hline Total Biaya Pesanan Khusus & $\mathrm{Rp} \mathrm{36.121.250}$ \\
\hline
\end{tabular}

Sumber : Berdasarkan hasil wawancara dengan pemilik UMKM

Perhitungan diatas maka Laporan Laba Ruginya adalah sebagai berikut :

$\begin{array}{lll}\text { Penjualan } & : 1500 \times \operatorname{Rp} 32.000=\mathrm{Rp} 48.000 .000 \\ \text { Biaya Produksi } & : 1.500 \times \mathrm{Rp} 24.080,83 \frac{\mathrm{Rp} 36.121 .245}{\mathrm{Rp} 11.878 .755} \\ \text { Laba Bersih } & \end{array}$

Berdasarkan perhitungan laba rugi dengan pesanan khusus yang berasal dari penjualan secara online ternyata UMKM Bast Grup mendapatkan pendapatan sebesar
Rp 48.000.000, biaya produksi yang dikeluaran sebesar $\mathrm{Rp}$ 36.121.245 dan mendapatkan laba bersih sebesar $\mathrm{Rp}$ 11.878.000. 
Analisis Diferensial dengan tanpa pesanan khusus bulan Juli 2020 pada UMKM Bast Grup

Tabel 3. Analisis Diferensial dengan dan tanpa pesanan khusus

\begin{tabular}{|c|c|c|c|}
\hline Keterangan & $\begin{array}{c}\text { Tanpa Pesanan } \\
\text { Khusus/Tanpa } \\
\text { Biaya } \\
\text { Diferensial } \\
\text { (1) }\end{array}$ & $\begin{array}{c}\text { Dengan Pesanan } \\
\text { Khusus/Dengan } \\
\text { Biaya Diferensial } \\
\text { (2) }\end{array}$ & Perbedaan \\
\hline \multicolumn{4}{|l|}{ Penjualan : } \\
\hline 1.000 x Rp 32.000 & Rp 32.000.000 & Rp 32.000.000 & 0 \\
\hline $1.500 \times \operatorname{Rp} 32.000$ & - & Rp 48.000.000 & $\mathrm{Rp} 48.000 .000$ \\
\hline Jumlah & Rp 32.000.000 & Rp 80.000.000 & Rp 48.000.000 \\
\hline \multicolumn{4}{|l|}{ Biaya Produksi : } \\
\hline 1.000 x Rp 24.690 & Rp 24.690.000 & $\operatorname{Rp} 24.690 .000$ & 0 \\
\hline $1.500 \times \operatorname{Rp} 24.080,83$ & - & $\operatorname{Rp} 36.121 .245$ & $\operatorname{Rp} 36.121 .245$ \\
\hline Total Biaya Produksi & Rp 24.690.000 & $\operatorname{Rp} 60.811 .245$ & $\operatorname{Rp} 36.121 .245$ \\
\hline Laba Bersih & Rp 7.310.000 & Rp 19.188.755 & Rp 11.878.755 \\
\hline
\end{tabular}

Sumber : Berdasarkan hasil perhitungan dengan menggunakan metode pesanan khusus

Pada analisis diatas UMKM Bast Grup di Kecamatan Gunung Putri memproduksi rata-rata 1.000 sarung tangan dengan harga $\mathrm{Rp} 32.000$, jumlah pendapatan di bulan Juli rata-rata tanpa pesanan khusus sebesar Rp 32.000.000, Jika UMKM Bast Grup menjual sarung tangan di media sosial dengan perkiraan penambahan sebanyak 500 sarung tangan dengan harga $\mathrm{Rp}$ 30.000, maka pendapatan yang akan diperoleh BAST Grup Sebesar Rp 48.000.000, Perbedaan selisih laba bersih dengan dan tanpa pesanan khusus sebesar Rp 11.878.755, maka altenatif yang terbaik yang digunakan oleh manajemen dalam memproduksi sarung tangan ialah dengan berjualan melalui media sosial namun tetap menerima pesanan secara offline.

Berdasarkan hasil perhitungan diatas diperoleh perhitungan biaya produksi tanpa pesanan khusus Rp $24.690 .000: 1.000=\mathrm{Rp}$ 24.690, harga jual yang ditentukan oleh UMKM Bast Grup yaitu sebesar Rp 32.000 dan keuntungan yang didapatkan dalam satu pasang sarung tangan ialah sebesar Rp 7.310. hasil perhitungan biaya produksi dengan pesanan khusus yang berasal dari penjualan online yaitu : Rp 36.121.245 : $1.500=\operatorname{Rp} 24.080,83$, harga jual yang ditentukan oleh UMKM Bast Grup yaitu sebesar 32.000, dan keuntungan yang didapatkan dalam satu pasang sarung tangan ialah sebesar Rp 7.919,17. Dengan adanya perhitungan biaya diferensial dalam metode menerima / menolak pesanan khusus pada UMKM Bast Grup yang ratarata memproduksi tiap bulannya sebanyak 1.000 sarung tangan dengan pendapatan yang didapatkan sebesar Rp 32.000. jika UMKM Bast Grup menggunakan pemanfaatan teknologi informasi dengan memanfaatkan whatsapp dan instagram jika perkiraan mendapatkan pesanan sebanyak 500 dengan harga yang sama dengan pesanan tanpa khusus maka pendapatan yang akan didapatkan yaitu sebesar $\mathrm{Rp}$ 48.000.000, maka perhitungan laba rugi 
secara keseluruhan tanpa metode pesanan khusus ialah sebesar Rp 7.310.000 yang berasal dari hitungan harga biaya produksi yang didapatkan sebesar Rp 24.690. Perhitungan laba rugi secara keseluruhan dengan pesanan khusus dari penjualan secara online ialah sebesar Rp 11.878.755 yang berasal dari hitungan harga biaya produksi yang didapatkan sebesar Rp 24.080,83. Keputusan altenatif yang digunakan UMKM Bast Grup adalah menerima pesanan khusus yang berasal dari media sosial. Berdasarkan perhitungan biaya diferensial sebagai alternatif pengambilan keputusan menerima atau menolak pesanan khusus perusahaan dapat memutuskan alternatif keputusan dari adanya pesanan khusus tersebut. Hal ini sejalan dengan pendapat yang dikemukakan oleh Samryn (2015) yang menyatakan jika pendapatan tambahan lebih besar dari biaya diferensial maka pesanan khusus diterima, Jika pendapatan tambahan lebih kecil dari biaya tambahan maka pesanan khusus sebaiknya ditolak, dan Jika pendapatan tambahan sama dengan biaya tambahan maka manajemen dapat mempertimbangkan tambahan informasi dari faktor lain.

Ditengah pandemi ini peran teknologi semakin terus meningkat seiring dengan penggunaan nya dimasa sekarang. Saat ini banyak orang yang memanfaatkan media sosial sebagai ladang bisnis salah satu nya adalah WhatsApp dan Instagram, hal yang perlu dilakukan oleh BAST Grup yaitu mengganti akun pribadi menjadi akun bisnis baik di Whatsapp maupun di Instagram. Di akun Whatsapp dan Instagram Bast Grup bisa mengupdate atau mengupload produk-produk melalui Whatsapp story, Instagram Story, dan upload di Beranda Instagram. Pemotretan produk baik itu foto atau video yang menarik, dan mengadakan promosi sehingga siapapun yang berminat bisa langsung memesan kepada Bast Grup.

Dokumen selama kegiatan berlangsung :

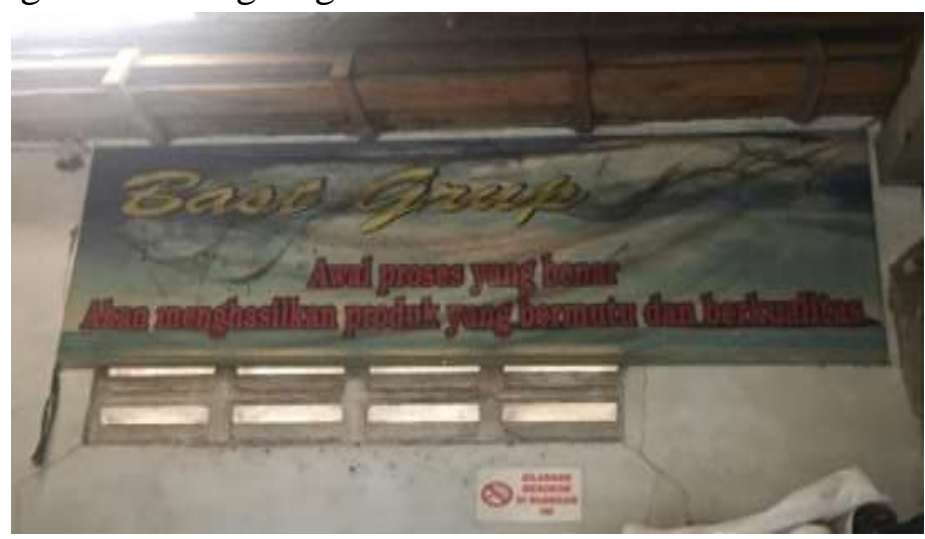

Gambar 1. Nama UMKM yang mengelola kulit Sapi dan Kamping 


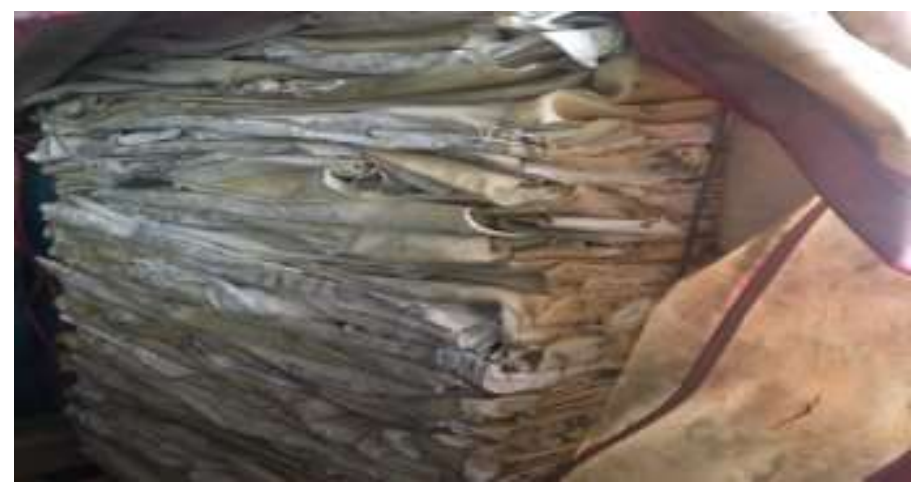

Gambar 2. Kulit Sapi dan Kambing yang diolah

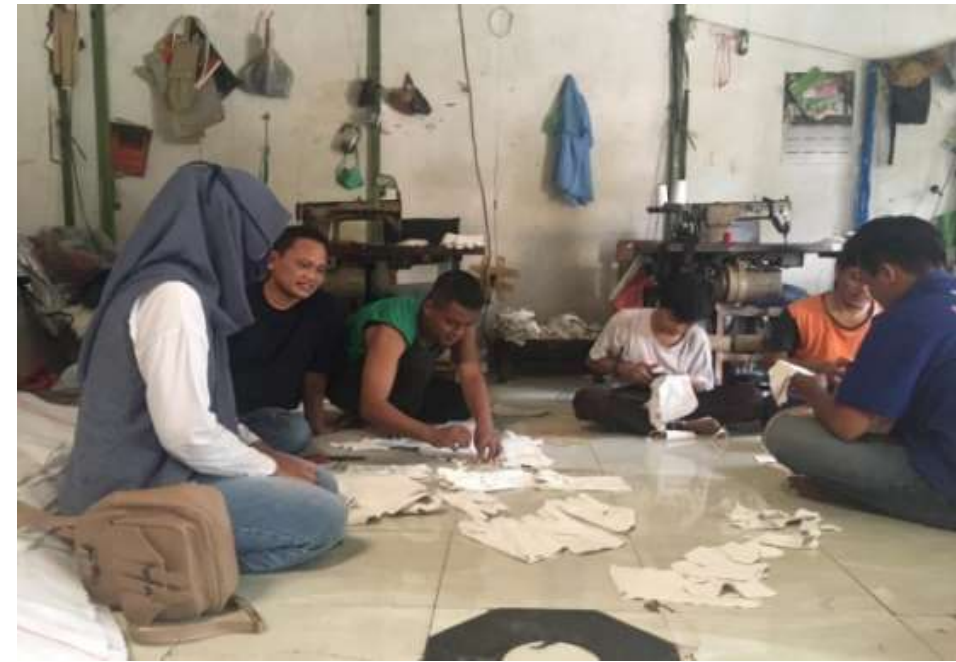

Gambar 3. Proses pengerjaan sarung tangan

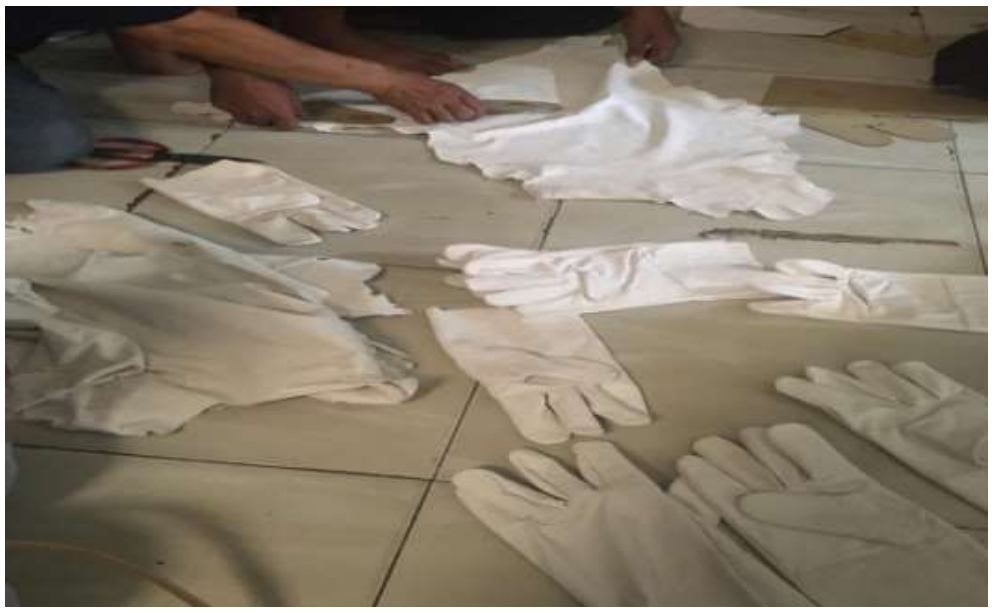

Gambar 4. Sarung tangan yang sudah dibentuk

\section{KESIMPULAN}

Perhitungan biaya diferensial dapat dijadikan sebagai dasar dalam mengambil keputusan untuk melakukan pemesanan khusus yang berasal dari penjualan melalui media sosial yang dilakukan oleh manajemen UMKM. Dengan menghitung total biaya produksi yang dikeluarkan ditambah dengan keuntungan yang diinginkan oleh UMKM tersebut.

Hasil perhitungan dengan dimasukkan nya biaya diferensial sebagai dasar pengambilan keputusan apakah akan 
menerima pesanan yang berasal dari media sosial oleh seorang manajemen pada UMKM Bast Grup di Kecamatan Gunungputri pada bulan Juni dapat diterima. Karena dengan perhitungan yang sudah dilakukan sudah memenuhi kriteria pengambilan keputusan dengan menerima pesanan khusus yang berasal dari penjualan

\section{DAFTAR PUSTAKA}

Prasetya, E. (2018). Pemberdayaan Masyarakat Tentang Kesehatan, Pendidikan dan Kreatifitas. Abdi Dosen: Jurnal Pengabdian Pada Masyarakat 2 (1), 19-25.

Sundarta, M Imam, Melati, Pitri, 2013, Penerapan Metode Just In Time Terhadap Sediaan Bahan Baku Dalam Rangka Meningkatkan Efisiensi Biaya Produksi Pada PT. Cipta Sarana Kenayu Lestari, Hal : 15-35

https://www.researchgate.net/publication/2 76108971_Pemanfaatan_Teknologi_ media sosial. Ini merupakan altenatif yang baik jika dijalankan di masa pandemi ini, selain mendapat keuntungan melalui offline, Bast Grup bisa mendapatkan keuntungan dari penjualan online dengan hanya menggunakan fasilitas Wifi untuk mempromisikan produksinya.

Informasi_Pengembangan_Bisnis_Po $\underline{\mathrm{S}}$

https://www.diskes.baliprov.go.id/wapadacoronavirus-covid-19-kenalipenyebabnya-dan-lakukanpencegahannya/

https://www.google.com/amp/s/akuntansite rapan.com/2010/06/16/biayarelevan-untuk-pengambilankeputusan/amp

https://ejournal.undiksha.ac.id/index.php/JJ $\underline{\mathrm{PE} / \mathrm{article} / \mathrm{view} / 20091}$ 